\title{
PENGARUH KEPEMIMPINAN TRANSFORMASIONAL DAN KEMAMPUAN TERHADAP KOMITMEN ORGANISASI DENGAN KEPUASAN KERJA SEBAGAI VARIABEL INTERVENING (STUDI PADA BALAI PENDIDIKAN DAN PELATIHAN APARATUR SUKAMANDI)
}

\section{LEADERSHIP TRANSFORMASIONAL AND ABILITY IMPACT TOWARDS ORGANIZATIONAL COMMITMENT USING JOB SATISFACTION AS INTERVENING VARIABLES \\ (CASE STUDY AT SUKAMANDI APPARATUS TRAINING CENTER)}

\author{
Wahyu Yulianto \\ Balai Diklat Aparatur Kementerian Kelautan dan Perikanan \\ Jl. Raya 2 Sukamandi, Ciasem 41256, Subang-Jawa Barat \\ Email: wahyuyuliantokkp@gmail.com
}

\begin{abstract}
The study purpose is to analyse the impact leadership transformasional and ability towards organization commitment either directly or through job satisfaction as a intervening variable. There are 66 staff involved as respondents in this study, and taken as sampling using census method. Primary data in this study is collected using questionnaire and then analyzed using Likert. Secondary data is obtained from Institution's Annual Report of Sukamandi Apparatus Training Centre (BDA). Furthermore, data is explored using descriptive and Structural Equation Modelling (SEM) with Partial Least Square (PLS).

This study shows leadership transformasional and ability significant impact on organization commitment. Job satisfaction is significant in intervening the effect of leadership transformasional and ability on organization commitment.
\end{abstract}

Keyword: job satisfaction, leadership transformasional, ability, organization commitment.

\begin{abstract}
ABSTRAK
Penelitian ini bertujuan untuk menganalisis pengaruh kepemimpinan transformasional dan kemampuan terhadap komitmen organisasi dengan kepuasan kerja sebagai variabel intervening. Responden dalam penelitian ini sebanyak 66 pegawai. Metode penarikan sampel menggunakan teknis sensus. Data primer yang diperlukan dalam penelitian ini dikumpulkan melalui kuesioner dengan menggunakan Skala Likert. Data sekunder diperoleh melalui Laporan Tahunan Balai Pendidikan dan Pelatihan Aparatur (BDA) Sukamandi. Analisis menggunakan teknik analisis deskriptif dan metode Structural Equation Modelling (SEM) Partial Least Square (PLS).

Penelitian ini menunjukkan bahwa kepemimpinan transformasional dan kemampuan berpengaruh signifikan terhadap komitmen organisasi. Kepuasan kerja mampu memediasi pengaruh kepemimpinan transformasional dan kemampuan terhadap komitmen organisasi.

Kata kunci: Kepemimpinan Transformasional, Kemampuan, Kepuasan Kerja, Komitmen Organisasi
\end{abstract}

\section{A. PENDAHULUAN}

Organisasi adalah suatu kelompok orang yang beranggotakan lebih dari satu orang, yang bekerja bersama-sama untuk mencapai suatu tujuan tertentu (Hasibuan 2002). Setiap organisasi yang ada saat ini dituntut untuk terus mengembangkan dan meningkatkan kualitas sumber daya yang dimiliki oleh organisasi tersebut agar mampu berperan dalam persaingan 
global (Melia dan Sukmawati 2011). Salah satu dari sumber daya tersebut adalah Sumber Daya Manusia (SDM).

SDM dalam suatu organisasi perlu mendapat perhatian yang lebih mendalam, karena pada akhirnya, faktor manusialah yang menentukan keberhasilan atau kegagalan dalam suatu kebijaksanaan, strategi, maupun langkah-langkah kegiatan operasional yang siap dilaksanakan. Adanya sarana dan prasarana yang memadai namun apabila tidak didukung oleh sumber daya manusia yang berkualitas, maka organisasi dipastikan akan sangat sulit mengalami perkembangan (Liana dan Irawati 2014).

Balai Pendidikan dan Pelatihan Aparatur (BDA) Sukamandi adalah satuan kerja dari Kementerian Kelautan dan Perikanan (KKP). BDA Sukamandi mempunyai tugas melaksanakan pendidikan dan pelatihan teknis dan manajerial di bidang pengembangan aparatur. BDA Sukamandi mempunyai visi mencetak sumber daya kelautan dan perikanan yang kompeten, dengan visi ini diharapkan dapat terlaksananya penyelenggaraaan diklat yang berkualitas dalam upaya pengembangan aparatur dilingkup KKP yang mampu mengemban tugas pemerintah serta dapat secara efektif dan efesien melaksanakan pembangunan fisik dan non fisik di BDA Sukamandi dengan didukung oleh penyelenggaraan kegiatan yang produktif, transparan, bersih dan bertanggung jawab serta bebas dari KKN. Untuk mewujudkan visi tersebut, BDA Sukamandi memiliki misi yaitu penyelenggaraan diklat yang berstandar.

SDM harus dikelola dengan sebaik-baiknya agar efektivitas dan efisiensi organisasi semakin meningkat. Organisasi harus berupaya untuk memberdayakan SDM yang dimilikinya dengan optimal. Salah satu upaya yang dilakukan oleh organisasi adalah dengan cara membangun komitmen pegawainya dalam rangka meningkatkan kualitasnya. Keberhasilan suatu organisasi dalam mengelola SDM yang dimilikinya akan meningkatkan komitmen yang dimiliki oleh pegawainya.

Pelaksanaan tugas disemua bagian lingkungan BDA Sukamandi sangat memerlukan kekompakan dan kerjasama tim yang kuat baik dari sisi SDM, keuangan maupun operasionalnya. Artinya, pelatihan yang telah terprogram dan diputuskan dalam rapat secara mekanis akan dilaksanakan sesuai jadwal, karena secara mekanis pula telah mendapat dukungan baik dari sisi SDM, keuangan dan fasilitas.

Komitmen organisasi merupakan suatu keadaan yang berdampak pada perilaku positif yang kuat, yang dirasakan oleh pegawai terhadap organisasi kerja yang dimilikinya. Komitmen organisasi tidak hanya terbatas pada kesetiaan organisasi, tetapi pada proses yang dilakukan oleh pegawai dalam bentuk kepedulian mereka terhadap organisasi dan mencoba untuk berprestasi tinggi (Melia dan Sukmawati 2011). Hal ini sesuai dengan apa yang dikemukakan oleh Hardaya dan Mulyanto (2009), bahwa komitmen memiliki kontribusi yang menonjol pada setiap organisasi, komitmen setiap pegawai akan menimbulkan dampak pada usaha pegawai untuk secara maksimal bekerja dalam rangka mencapai tujuan organisasi.

Organisasi yang berhasil dalam mencapai tujuan serta mampu memenuhi tanggung jawab sosialnya akan sangat tergantung pada para pimpinannya. Bila pimpinan mampu melaksanakan dengan baik, sangat mungkin organisasi tersebut akan mencapai sasarannya. Suatu organisasi membutuhkan pemimpin yang efektif, yang mempunyai kemampuan mempengaruhi perilaku anggotanya atau anak buah. Jadi, seorang pemimpin atau kepala suatu organisasi akan diakui sebagai seorang pemimpin apabila ia dapat mempunyai pengaruh dan mampu mengarahkan bawahannya kearah pencapaian tujuan organisasi.

Kepemimpinan transformasional merupakan salah satu diantara sekian model kepemimpinan, yang menurut Tracey dan Hinkin (1998) adalah sebagai sebuah proses saling meningkatkan diantara para pemimpin dan pengikut ke tingkat moralitas dan motivasi yang lebih tinggi. Gaya kepemimpinan transformasional merupakan prosedur pengaruh sadar 
dalam individu atau kelompok untuk membuat perubahan terus-menerus, perkembangan status quo dan kinerja organisasi secara keseluruhan (Avolio et al. 2004).

BDA Sukamandi dalam rangka mencapai tujuannya, mengalami beberapa permasalahan terkait dengan perilaku pegawai yang ada. Hal ini terlihat dari penilaian akreditasi yang dilakukan oleh Lembaga Administrasi Negara (LAN) bahwa ada penurunan nilai akreditasi di BDA Sukamandi (2015) yang disebabkan kemampuan pegawai dalam mengembangkan diri kurang. Masih adanya pegawai yang sering kali keluar di jam kerja dan juga yang bersantai di jam kerja, serta inisiatif dalam melaksanakan tugas menunggu untuk diperintah tanpa adanya inisiatif sendiri. Selain itu, seringkali terdapat ketidakpuasan terhadap kebijakan yang telah dibuat oleh pimpinan, baik yang menyangkut pribadi maupun organisasi. Adanya permasalahan ini akan berdampak pada pekerjaan yang menjadi tugas dan tanggung jawab mereka sehingga tidak bisa diselesaikan dengan efektif dan efisien. Terkait dengan permasalahan tersebut, maka penelitian terhadap komitmen pegawai melalui kepemimpinan transformasional dan kemampuan menjadi sangat penting.

\section{B. METODE PENELITIAN}

Penelitian ini bertujuan menganalisis pengaruh gaya kepemimpinan transformasional dan kemampuan terhadap komitmen organisasi dengan kepuasan kerja sebagai variabel intervening di BDA Sukamandi. Populasi dalam penelitian ini adalah seluruh pegawai BDA Sukamandi yang berstatus PNS dan kontrak berjumlah 66 (enam puluh enam) orang. Sampel adalah bagian dari jumlah dan karakteristik yang dimiliki oleh populasi (Sugiyono 2008). Sampel dalam penelitian ini adalah keseluruhan anggota populasi. Penelitian yang menggunakan seluruh anggota populasinya atau disebut sensus. Penggunaan metode ini berlaku jika anggota populasi relatif kecil (mudah dijangkau). Teknik atau metode yang akan digunakan dalam pengumpulan data menggunakan metode kuesioner dan wawancara. Analisis data yang digunakan dalam penelitian ini adalah SEM PLS.

\section{KERANGKA TEORI}

\section{Kepemimpinan Transformasional}

Pemimpin transformasional adalah pemimpin yang menginspirasi para pengikutnya untuk mengenyampingkan kepentingan pribadi mereka demi kebaikan organisasi dan mereka mampu memiliki pengaruh yang luar biasa pada diri para pengikutnya. Mereka menaruh perhatian terhadap kebutuhan pengembangan diri para pengikutnya, mengubah kesadaran para pengikut atas isu-isu yang ada dengan cara membantu orang lain memandang masalah lama dengan cara yang baru, serta mampu menyenangkan hati dan menginspirasi para pengikutnya untuk bekerja keras guna mencapai tujuan-tujuan bersama (Robbins dan Judge 2008).

Menurut Sopiah (2008) dan Yukl (2010), kepemimpinan transformasional terdiri dari empat aspek yang meliputi: pengaruh yang ideal (idealized influence), motivasi yang inspirasional (inspirational motivation), stimulasi intelektual (intellectual stimulation), dan pertimbangan yang bersifat individual (individualized consideration). Keempat aspek kepemimpinan transformasional tersebut mendorong karyawan untuk bekerja lebih keras, meningkatkan produktifitas, memiliki moril kerja serta kepuasan kerja yang lebih tinggi, meninggikan efektifitas organisasi, meminimalkan perputaran karyawan, menurunkan tingkat ketidakhadiran, dan memiliki kemampuan menyesuaikan diri secara organisasional yang lebih tinggi (Robbins dan Judge 2008).

\section{Kemampuan}

Menurut Robbin dan Judge (2008) kemampuan adalah kapasitas seseorang individu untuk melakukan beragam tugas dalam suatu pekerjaan. Menurut Gibson et al (2009), kemampuan adalah sifat yang dibawa sejak lahir/dipelajari yang memungkinkan seseorang 
menyelesaikan tugasnya. Kemampuan menunjukkan potensi orang untuk melaksanakan tugas/pekerjaan. Kemampuan pegawai dalam melaksanakan tugasnya merupakan perwujudan dari pengetahuan dan keterampilan yang dimiliki. Tidak semua karyawan memiliki kemampuan untuk bekerja dengan baik meskipun sudah dimotivasi dengan baik.

Kemampuan merupakan kecakapan seseorang yang meliputi kecerdasan dan keterampilan dalam memecahkan persoalan yang dihadapinya (Wursanto 2003). Kemampuan kerja menunjukkan kecakapan seseorang seperti kecerdasan dan keterampilan. Kemampuan berhubungan erat dengan kemampuan fisik dan mental yang dimiliki orang untuk melakaksanakan pekerjaan. Handoko (2013) menjelaskan bahwa terdapat faktor-faktor yang menentukan kemampuan kerja seseorang yaitu : 1) Faktor pendidikan formal, 2) Faktor pelatihan 3) Faktor pengalaman kerja.

\section{Kepuasan Kerja}

Menurut Colquitt et al. (2009) kepuasan kerja adalah kondisi emosi yang menyenangkan sebagai akibat dari penilaian kerja atau pengalaman kerja karyawan. Kepuasan kerja merupakan keadaan emosi positif yang berasal dari penilaian terhadap pekerjaan atau pengalaman kerja seseorang (Luthans 2006). Zafar et al. (2014) menyebutkan bahwa kepuasan kerja adalah keadaan yang menyenangkan dan positif merupakan salah satu yang dimiliki dari pengalaman kerjanya atau dengan kata lain persepsi karyawan tentang bagaimana pekerjaan mereka menyediakan mereka hal-hal yang mereka anggap penting bagi mereka. Jusmin et al. (2015) menerangkan bahwa kepuasan adalah evaluasi yang menggambarkan perasaan seseorang bahagia atau tidak bahagia, puas atau tidak puas dengan pekerjaan.

Robbins (2006) menyatakan bahwa aspek kepuasan kerja meliputi pekerjaan yang menantang, penghargaan yang sesuai, kondisi kerja yang mendukung, rekan kerja yang mendukung. Pekerja yang memiliki tingkat kepuasan kerja tinggi umumnya mencintai pekerjaan mereka. Mereka merasa keadilan dalam suatu lingkungan di mana mereka bekerja, dan merasa bahwa pekerjaan mereka memberi mereka beberapa fitur positif seperti variasi, tantangan, membayar pekerja dengan baik dan keamanan, otonomi, menyenangkan rekan kerja, dll.

\section{Komitmen Organisasi}

Komitmen organisasi merupakan sikap yang mencerminkan sejauh mana seseorang individu atau pegawai mengenal dan terikat pada organisasinya (Griffin 2004). Bagraim (2007) menyatakan bahwa komitmen dapat berkembang apabila pegawai mampu menemukan harapannya dan memenuhi kebutuhannya dalam sebuah organisasi. Robbins dan Judge (2008) menyatakan bahwa komitmen adalah suatu keadaan dimana seorang pegawai memihak kepada sesuatu organisasi tertentu dan tujuan-tujuannya serta berniat memelihara keanggotaan dalam organisasi itu. Mathis dan Jackson (2006) menyatakan komitmen organisasi sebagai keadaan dimana karyawan percaya dan mau menerima tujuan-tujuan organisasi dan akan tetap tinggal atau tidak akan meninggalkan organisasinya. Pengukuran komitmen karyawan menggunakan empat indikator yang dikembangkan oleh Mowday et al. (1982) yaitu: 1. Keinginan kuat tetap sebagai anggota, 2. Keinginan berusaha keras dalam bekerja, 3. Penerimaan nilai organisasi, 4. Penerimaan tujuan organisasi.

Colquitt et al. (2009) menjelaskan faktor yang mempengaruhi komitmen organisasi antara lain kepemimpinan transformasional, motivasi, kemampuan dan kepuasan kerja. Berdasarkan latar belakang penelitian di atas maka dapat diasumsikan bahwa kepemimpinan transformasional, motivasi, kemampuan dan kepuasan kerja dapat memberikan pengaruh terhadap komitmen organisasi. Untuk memperjelas kerangka berfikir tersebut maka dapat dilihat pada gambar 1 di bawah ini : 


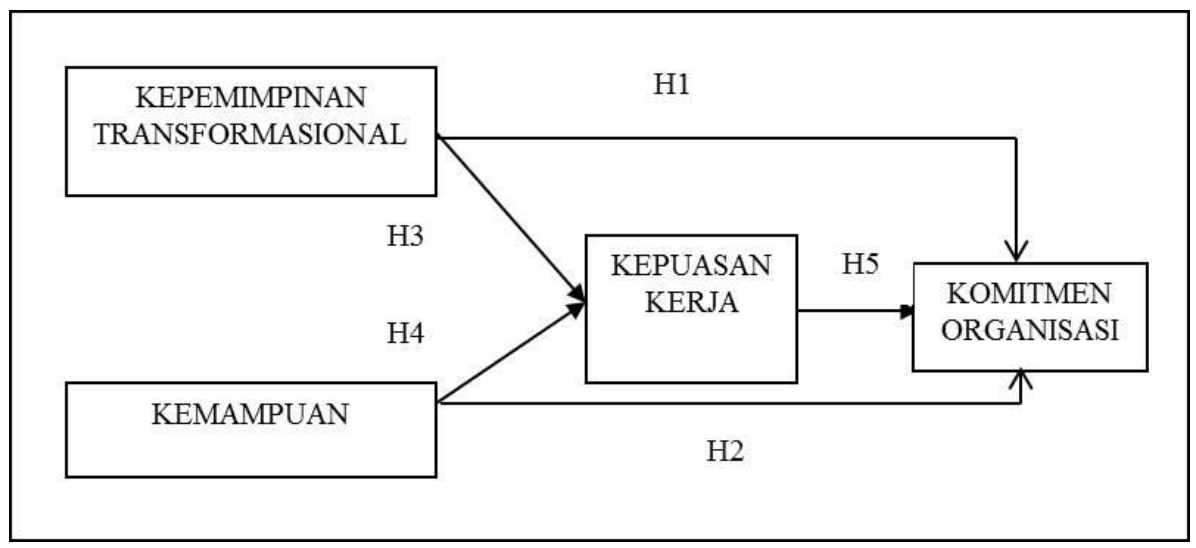

Gambar 1. Kerangka Pemikiran

Hipotesis dalam penelitian ini adalah sebagai berikut :

1. Kepemimpinan transformasional berpengaruh positif terhadap komitmen organisasi BDA Sukamandi

2. Kemampuan berpengaruh positif terhadap komitmen organisasi BDA Sukamandi

3. Kepemimpinan transformasional berpengaruh positif terhadap kepuasan kerja BDA Sukamandi

4. Kemampuan berpengaruh positif terhadap kepuasan kerja BDA Sukamandi

5. Kepuasan kerja berpengaruh positif terhadap komitmen organisasi BDA Sukamandi

\section{HASIL DAN PEMBAHASAN \\ Teknik Analisis Data}

Teknik analisis data dalam penelitian ini menggunakan analisis deskriptif untuk menguji hubungan karakteristik responden dan Structural Equation Modelling (SEM) dengan Partial Least Square (PLS) untuk menganalisis pengaruh variabel penelitian. Menurut Ghozali (2014) Structural Equation Modeling (SEM) merupakan suatu teknik analisis statistik multivariat, yang memungkinkan peneliti untuk menguji pengaruh langsung dan tidak langsung antara variabel yang kompleks, baik searah (recursive) maupun tidak searah (non-recursive) untuk memperoleh gambaran menyeluruh mengenai suatu model.

\section{Uji Validitas dan Reliabilitas Kuesioner}

Pada penelitian ini, uji validitas dilakukan dengan membandingkan hasil perhitungan koefisien butir ( $\mathrm{r}$ hitung) dengan hasil perhitungan ( $\mathrm{r}$ tabel) dari 66 sampel penelitian dengan teknik korelasi Pearson Product Moment.

Apabila $r$ hitung positif dan $r$ hitung $>r$ tabel, maka butir instrument tersebut valid. Hasil perhitungan koefisien butir ( $\mathrm{r}$ hitung) pada kuesioner penelitian ini menunjukkan nilai positif dan ( $\mathrm{r}$ hitung) $>$ ( $\mathrm{r}$ tabel), yaitu $>0.3610$ jadi semua pertanyaan pada kuesioner dianggap valid, hasil uji validitas kuesioner. Uji reliabilitas dilakukan dengan membandingkan hasil perhitungan koefisien butir ( $\mathrm{r}$ alpha) dengan hasil perhitungan ( $\mathrm{r}$ tabel) dari 66 sampel penelitian dengan teknik korelasi Cronbach's Alpha. Apabila ( $\mathrm{r}$ alpha) positif dan ( $\mathrm{r}$ alpha) $>$ ( $\mathrm{r}$ tabel), yaitu $>0.60$ maka butir instrument tersebut valid. Nilai Cronbach's Alpha ( $\mathrm{r}$ alpha) untuk masing-masing variabel berdasarkan uji reliabilitas pada penelitian ini semuanya > dari 0.60 sehingga kuesioner dalam penelitian ini dianggap reliabel.

\section{Uji Measurement (outer) Model}

Outer model dinilai dengan cara melihat convergent validity (besarnya loading factor untuk masing-masing konstruk). Indikator dianggap reliable jika memiliki nilai korelasi diatas 0.70. Berdasarkan kriteria tersebut dilakukan pengujian hasil pengujian outer model. 
Hasil pengujian outer model, yang telah memenuhi standar convergent validity (reliable) yaitu semua factor loading berada diatas 0.70 .

Tabel 1 Hasil Uji Outer Loading

\begin{tabular}{|l|r|r|r|r|}
\hline \multicolumn{1}{|c|}{ Indikator } & Kepemimpinan & Kemampuan & Komitmen & Kepuasan \\
\hline Komitmen Organisasi 1 & & & 0.946 & \\
\hline Komitmen Organisasi 2 & & & 0.797 & \\
\hline Komitmen Organisasi 3 & & & 0.943 & \\
\hline Komitmen Organisasi 4 & & & 0.850 & \\
\hline Kemampuan 1 & & 0.874 & & \\
\hline Kemampuan 2 & & 0.724 & & \\
\hline Kemampuan 3 & 0.889 & & & \\
\hline Kepemimpinan Transformasional 1 & 0.774 & & & \\
\hline Kepemimpinan Transformasional 2 & 0.736 & & & \\
\hline Kepemimpinan Transformasional 3 & 0.797 & & & \\
\hline Kepemimpinan Transformasional 4 & & & & 0.944 \\
\hline Kepuasan Kerja 1 & & & & 0.969 \\
\hline Kepuasan Kerja 2 & & & & 0.950 \\
\hline Kepuasan Kerja 3 & & & & 0.745 \\
\hline Kepuasan Kerja 4 & & & & \\
\hline
\end{tabular}

Sumber: Data Primer, 2018 (diolah)

Tabel 2 Hasil Uji Cross Loading

\begin{tabular}{|l|r|r|r|r|}
\hline \multicolumn{1}{|c|}{ Indikator } & Kepemimpinan & Kemampuan & Komitmen & Kepuasan \\
\hline Komitmen Organisasi 1 & 0.737 & 0.505 & 0.946 & 0.644 \\
\hline Komitmen Organisasi 2 & 0.647 & 0.352 & 0.797 & 0.475 \\
\hline Komitmen Organisasi 3 & 0.689 & 0.457 & 0.943 & 0.629 \\
\hline Komitmen Organisasi 4 & 0.680 & 0.474 & 0.850 & 0.601 \\
\hline Kemampuan 1 & 0.776 & 0.874 & 0.828 & 0.560 \\
\hline Kemampuan 2 & 0.756 & 0.724 & 0.616 & 0.679 \\
\hline Kemampuan 3 & 0.652 & 0.830 & 0.613 & 0.910 \\
\hline Kepemimpinan Transformasional 1 & 0.889 & 0.591 & 0.639 & 0.347 \\
\hline Kepemimpinan Transformasional 2 & 0.774 & 0.824 & 0.397 & 0.641 \\
\hline Kepemimpinan Transformasional 3 & 0.736 & 0.724 & 0.555 & 0.319 \\
\hline Kepemimpinan Transformasional 4 & 0.797 & 0.830 & 0.340 & 0.745 \\
\hline Kepuasan Kerja 1 & 0.672 & 0.694 & 0.640 & 0.944 \\
\hline Kepuasan Kerja 2 & 0.716 & 0.459 & 0.824 & 0.969 \\
\hline Kepuasan Kerja 3 & 0.715 & 0.455 & 0.630 & 0.950 \\
\hline Kepuasan Kerja 4 & 0.713 & 0.468 & 0.626 & 0.745 \\
\hline
\end{tabular}

Sumber: Data Primer, 2018 (diolah)

\section{Uji Validitas Konstruk}

Uji validitas konstruk dilakukan dengan melihat nilai Average Variance Extracted $(A V E)$. Konstruk dikatakan valid/baik apabila AVE dari masing-masing konstruk nilainya > 0.50. Hasil uji yang dilakukan menunjukkan bahwa nilai AVE dari masing-masing konstruk memiliki nilai > 0.05, hal ini menunjukkan bahwa konstruk dapat dikatakan valid dan baik. 
Tabel 3 Hasil Uji Average Variance Extracted (AVE)

\begin{tabular}{lc}
\hline \multicolumn{1}{c}{ Indikator } & Average Variance Extracted $(A V E)$ \\
\hline Komitmen Organisasi & 0.675 \\
Kepuasan Kerja & 0.724 \\
Kepemimpinan Transformasional & 0.770 \\
Kemampuan & 0.715 \\
\hline
\end{tabular}

Sumber: Data diolah (2018)

\section{Uji Reliabilitas Konstruk}

Uji reliabilitas konstruk dapat dilakukan dengan dua kriteria pengukuran, yaitu composite reliability dan cronbach alpha dari blok indikator yang mengukur konstruk. Konstruk dinyatakan reliable jika nilai composite reliability maupun cronbach alpha di atas 0.70 (Ghozali 2014). Hasil output pengujian composite reliability dan cronbach alpha untuk masing-masing konstruk semuanya di atas 0.70 . Hal ini dapat disimpulkan bahwa konstruk tersebut memiliki reliabilitas yang baik.

\section{Tabel 4 Hasil Uji Composite Reliability}

\begin{tabular}{lc}
\hline \multicolumn{1}{c}{ Indikator } & Composite Reliability \\
\hline Komitmen Organisasi & 0.861 \\
Kepuasan Kerja & 0.929 \\
Kepemimpinan Transformasional & 0.910 \\
Kemampuan & 0.935 \\
\hline
\end{tabular}

Sumber: Data diolah (2018)

Tabel 5 Hasil Uji cronbach alpha

\begin{tabular}{lc}
\hline \multicolumn{1}{c}{ Indikator } & Composite Reliability \\
\hline Komitmen Organisasi & 0.758 \\
Kepuasan Kerja & 0.904 \\
Kepemimpinan Transformasional & 0.852 \\
Kemampuan & 0.903 \\
\hline ber: Data diolah (2018)
\end{tabular}

\section{Uji Model Struktural (Inner Model)}

Pengujian terhadap model struktural dilakukan dengan melihat nilai $R$-Square yang merupakan uji goodness-fit model. Tahap ini bertujuan untuk menganalisis tingkat estimasi antar variabel bebas (kepemimpinan transformasional dan kemampuan) dengan variabel intervening kepuasan kerja terhadap variabel terikat (komitmen organisasi). Kepemimpinan transformasional, kemampuan dan kepuasan kerja memengaruhi komitmen organisasi dengan nilai $R$-Square sebesar 0.439 , hal ini berarti variabilitas konstruk komitmen organisasi dapat dijelaskan oleh variabilitas konstruk kepemimpinan transformasional, kemampuan dan kepuasan kerja sebesar $43.9 \%$ sedangkan $56.1 \%$ dijelaskan oleh variabel lain di luar yang diteliti.

\section{Pengujian Hipotesis}

Uji Hipotesis dilakukan untuk menjawab persamaan penelitian. Untuk menjawab hipotesis yang diajukan dalam penelitian, dilakukan teknik bootstraping. Teknik bootstraping adalah teknik rekalkulasi data sampel secara random untuk memperoleh nilai T-statistik dan 
original sample dengan melakukan uji Path Coefficients. Berdasarkan nilai T-statistik yang diperoleh, dapat diketahui tingkat signifikansi pengaruh variabel independen ke variabel dependen. Apabila nilai T-statistik > 1.96 (T-Tabel signifikansi 5\%) maka pengaruhnya adalah signifikan dan sebaliknya. Selanjutnya berdasarkan nilai original sample yang diperoleh, dapat diketahui ada atau tidaknya pengaruh antara variabel independen dan variabel dependen. Apabila nilai original sample yang dihasilkan positif maka ada pengaruh yang dihasilkan dari variabel independen ke variabel dependen dan sebaliknya.

Tabel 6 Hasil Uji Path Coefficients teknik Bootstraping

\begin{tabular}{lccc}
\hline \multicolumn{1}{c}{ Path } & $\begin{array}{c}\text { T Statistics } \\
(\mid \text { OSTDEV } \mid)\end{array}$ & $\begin{array}{c}P \\
\text { Values }\end{array}$ & Hipotesis \\
\hline $\begin{array}{l}\text { Kepemimpinan Transformasional berpengaruh } \\
\text { terhadap Komitmen Organisasi }\end{array}$ & 6.709 & 0.003 & H1 diterima \\
$\begin{array}{l}\text { Kemampuan berpengaruh terhadap Komitmen } \\
\text { Organisasi }\end{array}$ & 8.301 & 0.004 & H2 diterima \\
$\begin{array}{l}\text { Kepemimpinan Transformasional berpengaruh } \\
\text { terhadap Kepuasan Kerja }\end{array}$ & 8.685 & 0.006 & H3 diterima \\
$\begin{array}{l}\text { Kemampuan berpengaruh terhadap Kepuasan } \\
\text { Kerja }\end{array}$ & 6.230 & 0.002 & H4 diterima \\
$\begin{array}{l}\text { Kepuasan Kerja berpengaruh terhadap } \\
\text { Komitmen Organisasi }\end{array}$ & 4.675 & 0.023 & H5 diterima \\
\hline
\end{tabular}

Sumber : Data diolah (2017)

\section{Pengujian Hipotesis 1 (H1)}

Hipotesis 1 (H1) "Kepemimpinan transformasional mempengaruhi komitmen organisasi". Uji path coefficients menunjukkan nilai T-Statistik $6.709>1.96$ dan $P$ Value $0.003<0.05$, ini berarti kepemimpinan transformasional secara langsung berpengaruh signifikan terhadap komitmen organisasi, $\mathrm{H} 1$ diterima.

\section{Pengujian Hipotesis 2 (H2)}

Hipotesis 2 (H2) "Kemampuan mempengaruhi komitmen organisasi". Uji path coefficients menunjukkan nilai T-Statistik $8.301>1.96$ dan $P$ Value $0.004<0.05$ untuk variabel kemampuan terhadap komitmen organisasi, ini berarti kemampuan secara langsung berpengaruh signifikan terhadap komitmen organisasi, $\mathrm{H} 2$ diterima.

\section{Pengujian Hipotesis 3 (H3)}

Hipotesis 3 (H3) "Kepemimpinan transformasional mempengaruhi kepuasan kerja". Uji path coefficients menunjukkan nilai T-Statistik $8.685>1.96$ dan $P$ Value $0.006<0.05$, ini berarti kepemimpinan transformasional secara langsung berpengaruh signifikan terhadap kepuasan kerja, H3 diterima.

\section{Pengujian Hipotesis 4 (H4)}

Hipotesis 4 (H4) "Kemampuan mempengaruhi kepuasan kerja". Uji path coefficients menunjukkan nilai T-Statistik $6.230>1.96$ dan $P$ Value $0.002<0.05$, ini berarti kemampuan secara langsung berpengaruh signifikan terhadap kepuasan kerja, $\mathrm{H} 4$ diterima.

\section{Pengujian Hipotesis 5 (H5)}

Hipotesis 5 (H5) "Kepuasan kerja mempengaruhi komitmen organisasi". Uji path coefficients menunjukkan nilai T-Statistik $4.675>1.96$ dan $P$ Value $0.023<0.05$, ini berarti kepuasan kerja secara langsung berpengaruh signifikan terhadap komitmen organisasi, H5 diterima.

\section{Pembahasan Hasil Penelitian}

Pembahasan secara deskriptif sesuai hasil penelitian di atas dapat dijelaskan sebagai berikut :

1. Kepemimpinan transformasional secara langsung berpengaruh signifikan terhadap komitmen organisasi, hal ini mendukung penelitian Lamidi (2009), Thomas dan Wahju 
(2007) bahwa kepemimpinan transformasional berpengaruh terhadap komitmen organisasional yang artinya bahwa kepemimpinan transformasional merupakan gaya kepemimpinan dimana pemimpin mampu menempatkan dirinya dengan baik diantara para bawahannya, memotivasi, dan mengartikulasikan pengharapan yang jelas terhadap prestasi bawahan, dengan begitu sekat antara bawahan dan pemimpin tidak begitu nampak, sehingga terjadi proses interaksi dan komunikasi yang nyaman antar keduanya yang mampu menciptakan rasa menghormati, percaya, dengan begitu hubungan pekerjaan dalam hal ini perintah pimpinan dapat diimplementasikan dan dijalankan bawahan sesuai dengan tujuan yang ingin dicapai secara maksimal. Kepemimpinan transformasional dapat menciptakan seorang karyawan memiliki komitmen organisasi yang tinggi. Seorang karyawan yang memiliki komitmen tinggi akan memiliki identifikasi dengan organisasi, terlibat sungguhsungguh dalam pekerjaan dan ada loyalitas serta afeksi positif terhadap organisasi. Dengan demikian dapat disimpulkan bahwa apabila seorang pemimpin memiliki kemampuan dalam menggerakan dan memberdayakan karyawan, maka dapat memengaruhi komitmen organisasi.

2. Kemampuan secara langsung berpengaruh signifikan terhadap komitmen organisasi, hal ini sesuai penelitian Yessi et al. (2016) bahwa kemampuan berpengaruh terhadap komitmen organisasional yang artinya bahwa kemampuan seseorang akan ditentukan oleh tinggi rendahnya tingkat pendidikan, pelatihan yang telah diikuti dan pengalaman. Sehingga dapat disimpulkan bahwa yang dimaksud dengan kemampuan pegawai dalam penelitian ini adalah semua potensi yang dimiliki pegawai untuk melaksanakan tugas berdasarkan pengetahuan, sikap, pengalaman, dan pendidikan. Tingkat pendidikan, pelatihan dan pengalaman yang rendah akan berdampak negatif pada komitmen organisasi. Sehingga pegawai dituntut untuk memiliki kualifikasi tertentu, karena tidak semua orang memiliki keahlian yang dipersyaratkan untuk menyelesaikan pekerjaan. Dari uraian di atas dapat disimpulkan bahwa kemampuan pegawai akan menentukan komitmen organisasi. Dengan kata lain semakin tinggi kemampuan pegawai dalam melaksanakan pekerjaannya maka semakin tinggi komitmen pegawai. Kemampuan kerja merupakan salah satu unsur dalam kematangan berkaitan dengan pengetahuan atau ketrampilan yang dapat diperoleh dari pendidikan, pelatihan dan suatu pengalaman (Thoha 2003).

3. Kepemimpinan Transformasional secara langsung berpengaruh signifikan terhadap kepuasan kerja, hal ini mendukung penelitian Kadek dan Made (2016) bahwa kepemimpinan transformasional berpengaruh terhadap kepuasan kerja yang artinya bahwa apabila pemimpin mampu menjadi teladan, membangkitkan antusiasme pegawai, memberikan motivasi dan menjalin kerjasama yang baik dengan pegawainya maka kepuasan kerja pegawai dalam melaksanakan pekerjaannya semakin baik pula.

4. Kemampuan secara langsung berpengaruh signifikan terhadap kepuasan kerja, hal ini sesuai penelitian Sidik dan Iwan (2013) bahwa kemampuan berpengaruh terhadap kepuasan kerja yang artinya bahwa kemampuan yang meliputi faktor pendidikan formal, faktor pelatihan dan faktor pengalaman akan sangat menentukan kepuasan kerja pegawai. Semakin tinggi tingkat kemampuan yang dimiliki pegawai maka akan semakin meningkatkan kepuasan kerjanya. Pegawai yang mempunyai pendidikan, pelatihan dan pengalaman yang baik dalam bekerja akan dapat berfikir konseptual dan memiliki keyakinan akan mampu melaksanaan pekerjaannya dengan baik. .

5. Kepuasan kerja secara langsung berpengaruh signifikan terhadap komitmen organisasi, hal ini sesuai penelitian Firmananda et al. (2016) bahwa kepuasan kerja berpengaruh terhadap komitmen organisasional yang artinya bahwa pegawai yang merasa terpuaskan dengan pekerjaannya akan secara sukarela mau mencurahkan semua perhatiannya dalam bekerja sehingga kinerjanya akan meningkat. Aspek kepuasan kerja yang meliputi pekerjaan yang 
memberikan tantangan, rekan kerja memiliki kemauan bekerjasama, lingkungan kerja yang nyaman dan kondusif serta kesesuaian kemampuan dan kepribadian pegawai dengan pekerjaannya apabila terpenuhi akan dapat meningkatkan komitmen organisasi. Mathis (2008) menjelaskan bahwa orang-orang yang relatif puas dengan pekerjaanya akan lebih berkomitmen pada organisasi dan orang-orang yang berkomitmen terhadap organisasi lebih mungkin mendapatkan kepuasan yang lebih besar.

\section{E. PENUTUP}

\section{a. Kesimpulan}

Berdasarkan hasil penelitian dan pembahasan, maka dapat diperoleh beberapa kesimpulan sebagai berikut:

1. Hasil penelitian menunjukkan terdapat pengaruh signifikan kepemimpinan transformasional terhadap komitmen organisasi sebesar 6,7 dan terdapat pengaruh signifikan kemampuan terhadap komitmen organisasi sebesar 8,3.

2. Hasil penelitian menunjukkan terdapat pengaruh yang signifikan antara kepemimpinan transformasional terhadap kepuasan kerja sebesar 8,6 dan terdapat pengaruh signifikan kemampuan terhadap kepuasan kerja sebesar ,2.

3. Hasil penelitian menunjukkan terdapat pengaruh yang signifikan antara kepuasan kerja terhadap komitmen organisasi sebesar 4,6.

\section{b. Saran}

Berdasarkan hasil penelitian dan pembahasan, maka saran yang dapat disampaikan adalah sebagai berikut:

1. Meningkatkan kemampuan pegawai dan kepemimpinan transformasional yang baik maka komitmen organisasi akan semakin meningkat. Kemampuan pegawai dapat ditingkatkan dengan mengikutsertakan pegawai pada pelatihan-pelathan teknis sesuai bidang tugasnya. Pemimpin dalam menerapkan kepemimpinan seharusnya lebih memperhatikan pegawai yang dipimpinnya. Keberpihakan pemimpin kepada pegawai akan dipersepsikan baik oleh pegawai, sehingga pegawai terdorong memiliki komitmen yang tinggi terhadap organisasi dengan dukungan kepemimpinan yang baik. Aspek yang harus diperhatikan dalam kepemimpinan yang baik antara lain bersifat adil, dapat menciptakan rasa aman dan bersikap menghargai. Upaya tersebut dapat dilakukan dengan memperkuat manajemen kepemimpinan melalui pendidikan dan pelatihan kepemimpinan yang berorientasi pada manajemen SDM.

2. Meningkatkan kemampuan dan kepemimpinan transformasional mampu menimbulkan kepuasan kerja yang berdampak terhadap peningkatan komitmen organisasi. Tindakan nyata dapat dilakukan adalah: 1) Penambahan intensitas pelatihan teknis yang sesuai dengan bidang pekerjaan yang didasarkan pada analisis kebutuhan pelatihan. 2) Melakukan roling/perputaran pegawai dalam rangka peningkatan kompetensi. 3) Penyusunan jenjang karier yang jelas. 4) Memberikan kesempatan kepada pegawai mengikuti lelang jabatan dalam rangka promosi. 5) Memberikan kesempatan kepada pegawai yang memiliki minat besar untuk berkarier dalam jabatan fungsional. 6) Pemimpin diharapkan dapat menerapkan praktek kepemimpinan yang efektif yang dipersepsikan baik oleh pegawai.

3. Variabel yang digunakan dalam penelitian ini meliputi kepemimpinan transformasional, kemampuan, kepuasan kerja dan komitmen organisasi. Untuk penelitian lebih lanjut, dapat ditambahkan beberapa variabel lain yang dapat mempengaruhi komitmen organisasi, 
mengingat nilai $R$-Square pada penelitian ini sebesar 0.439 atau $43,9 \%$. Sehingga masih terdapat $56,1 \%$ variabel lain yang dapat mempengaruhi komitmen organisasi, misalnya motivasi, keadilan dan budaya organisasi.

\section{DAFTAR PUSTAKA}

Avolio BJ, Zhu W, Koh W, Bhatia P. 2004. Transformational Leadership and Organizational Commitment: Mediating Role of Psychological Empowerment and Moderating Role of Structural Distance. Journal of Organizational Behavior. 25: 951-968.

Bagraim J, Sader R. 2007. Family-friendly Human Resources Policies Practices and Organizational Commitment. Management Dynamics. 16 (4): 2-12.

Colquitt JA, LePine J, Michel J, Weson. 2009. Organization Behavior. Improving Performance and Commitment in Workplace. New York (US): McGraw-Hill.

Firmananda HA, Djamhur H, Mochammad D. 2016. Pengaruh Kepuasan Kerja terhadap Komitmen Organisasional dan Kinerja Karyawan Studi pada Karyawan Tetap PG Kebon Agung Malang. Jurnal Administrasi Bisnis. 38 (2): 79-88.

Ghozali I. 2014. Konsep dan Aplikasi dengan Program PLS 3.0. Edisi 5. Semarang (ID): Universitas Diponegoro.

Gibson JL, Ivancevich JM, Donnelly JH. 2009. Organisasi, Perilaku, Struktur, dan Proses. Jakarta (ID): Binapura Aksara Publisher.

Griffin. 2004. Komitmen Organisasi. Terjemahan. Jakarta : Erlangga

Handoko HT.2013. Manajemen Personalia dan Sumber Daya Manusia.Edisi Kedua. Cetakan Ketigabelas. BPFE Yogyakarta.

Hardaya S , Mulyanto. 2009. Pengaruh Motivasi, Kepuasan Kerja dan Komitmen Organisasi terhadap Kinerja Pegawai pada Dinas Tenaga Kerja dan Transmigrasi Provinsi Daerah Istimewa Yogyakarta. Excellent 2 (2).

Hasibuan, Malayu SP. 2002. Manajemen Sumber Daya Manusia. Jakarta : PT Bumi Aksara.

Jusmin A, Said S, Bima MJ, Alam R. 2015. Specific Determinants of Work Motivation, Competence, Organizational Climate, Job Satisfaction and Individual Performance: A Study among Lecturers. Journal of Business and Management Sciences. 4(3):53-59.

Kadek NCD, Made S. 2016. Pengaruh Kepemimpinan Transformasional terhadap Kepuasan Kerja dan Turnover Intention pada CV. Gita Karya Persada Denpasar. E Jurnal Manajemen Unud. 4 (12) : 4219-4244.

Lamidi. 2009. Pengaruh Kepemimpinan Transformasional terhadap Komitmen Organisasi dengan Variabel Moderating Kepuasan Kerja Pegawai RS Swasta PKU Muhamadiyah Surakarta. Jurnal Ekonomi dan Kewirausahaan. 9 (1): 12-22.

Liana Y, Irawati R. 2014. Peran Motivasi, Disiplin Kerja terhadap Komitmen Karyawan dan Kinerja Karyawan pada Perusahaan Air Minum di Malang Raya. Jurnal Manajemen dan Akuntansi 3 (1).

Mathis RL, Jackson JH. 2006. Manajemen Sumber Daya Manusia. Jakarta (ID): Salemba Empat.

Melia I, Sukmawati A. 2011. Analisis Komitmen Organisasi Melalui Quality Of Work Life (Studi Kasus Fakultas Ekonomi dan Manajemen Institut Pertanian Bogor). Jurnal Manajemen dan Organisasi 2 (3).

Mowday RT, Porter LW, Steers RM. 1982. Employee-Organization Linkages: The Psychology of Commitment, Absenteeism, and Turnover. Academic Press. New York.

Robbins SP. 2006. Perilaku Organisasi. Edisi XI. Jakarta (ID): PT Indeks.

Robbins SP, Judge TA. 2008. Perilaku Organisasi. Edisi 2. Penerbit Salemba Empat. 
Sidik P dan Iwan R. 2013. Pengaruh Kemampuan Kerja dan Motivasi terhadap Kepuasan Kerja serta Implikasinya pada Kinerja Pegawai Dinas Pertambangan dan Energi Provinsi Jawa Barat. Jurnal Ekonomi, Bisnis dan Eterpreneurship. 7 (2): 52-63.

Sopiah. 2008. Perilaku Organisasional. Yogyakarta: Penerbit Andi.

Sugiyono. 2008. Metode Penelitian Kuantitatif, Kualitatif, dan R\&D. Bandung (ID): Alfabeta.

Thoha M. 2003. Perilaku Organisasi, Konsep Dasar dan Aplikasinya. Jakarta: Raja Grafindo Persada.

Thomas SK dan Wahju AR. 2007. Kepemimpinan Transformasional dan Pengaruhnya terhadap Kepuasan atas Kualitas Kehidupan Kerja, Komitmen Organisasi, dan Perilaku Ekstra Peran (Studi pada Guru-Guru SMU di Kota Surabaya). Jurnal Manajemen Dan Kewirausahan Universitas Kristen Petra. (9) 1: 49-61.

Tracey, J.B., and Hinkin, T.R. 1998. Transformational leadership or effective managerial practic, Group \& Organization Management. 23 (3): 220-236.

Wursanto Ig. 2003. Dasar-Dasar Ilmu Organisasi. Andi Offset. Yogyakarta

Yessi M, Muhammad IH dan Rizky F. 2016. Pengaruh Iklim Organisasi dan Kemampuan Kerja terhadap Komitmen Organisasional dan Dampaknya pada Kinerja Pegawai DISPERINDAGKOP dan UKM Kota Pontianak. Jurnal Ekonomi, Bisnis dan Kewirausahaan. 5 (3): 198-215.

Yukl, G. 2010. Kepemimpinan dalam Organisasi. Edisi Indonesia. Jakarta: Penerbit PT Indeks.

Zafar. N. (2014). Determinants of employee motivation and its impact on knowledge transfer and job satisfaction. International journal of human resource studies. 4: 50-69. 